\title{
INTRODUCING COOPERATIVE LEARNING IN THE ENGLISH LANGUAGE CLASSROOM AND PROGRESS TRACKING (AT THE DEPARTMENT OF TRANSLATION AND INTERPRETING IN SKOPJE)
}

\author{
Milena Sazdovska-Pigulovska \\ Ss Cyril and Methodius University, Skopje \\ milena.sazdovska@flf.ukim.edu.mk \\ Katarina Gjurčevska-Atanasovska \\ Ss Cyril and Methodius University, Skopje \\ katarina.gjurcevska@flf.ukim.edu.mk
}

The English language classroom has been experiencing a shift from the traditional approach towards a functional approach to teaching. The purpose is to abandon the classical lecture-and-note approach, passive role of students, an unproductive classroom and excessive teacher-reliance, thereby putting emphasis on interaction and collaboration in the English language classroom as well as on student autonomy in the learning process. The aim of this paper is to analyse efficient methods for teaching grammar and to explore which learning practices are deemed best by students. For the purposes of this research, a survey was conducted among 50 first-year students at the Faculty of Philology (whose progress in learning grammar was monitored in a period of two semesters). The results of the research indicate a need for applying an action-based approach in the English language classroom, whereas the authors suggest different cooperative learning strategies. Furthermore, the results demonstrate that teaching methods have an effect on the level of progress achieved by students, whereas the need for introducing progress tracking at faculty level is also discussed.

Keywords: cooperative teaching, learning strategies, EFL, progress tracking 


\title{
ВОВЕДУВАЊЕ КООПЕРАТИВНО УЧЕЊЕ ВО НАСТАВАТА ПО СОВРЕМЕН АНГЛИСКИ ЈАЗИК И СЛЕДЕЊЕ НА НАПРЕДОКОТ ВО УЧЕЊЕТО (НА КАТЕДРАТА ЗА ПРЕВЕДУВАҢЕ И ТОЛКУВАҢЕ ВО СКОПЈЕ)
}

\author{
Милена Саздовска-Пигуловска \\ Универзитет „Св. Кирил и Методиј“, Скопје \\ milena.sazdovska@flf.ukim.edu.mk \\ Катарина Ѓурчевска-Атанасовска \\ Универзитет „Св. Кирил и Методиј“, Скопје \\ katarina.gjurcevska@flf.ukim.edu.mk
}

Во наставата по современ англиски јазик, класичниот приод уште одамна е заменет со функционален приод. Целта е да се напуштат класичните предавања и пасивното фаќање белешки од страна на студентите и да се воведе интерактивно вклучување и соработка на студентите во процесот на учењето. Целта на овој труд е да се анализираат ефикасните методи на предавање, со посебен фокус врз граматиката. За целите на истражувањето е спроведено истражување меѓу 50 студенти од прва година на Филолошкиот факултет (чиј напредок во учењето е следен два семестри). Резултатите од истражувањето укажуваат на потреба од воведување учење засновано на задачи и примена на стратегии за кооперативно учење, при што се покажува дека методите на настава значително влијаат врз постигнувањата на студентите.

Клучни зборови: кооперативно подучување, стратегии на учење, современ англиски јазик, следење напредок 


\section{Subject and Purpose of the Research}

As a result of educational reforms conducted in the Republic of North Macedonia, the English language classroom at many universities has been undergoing significant changes in terms of teaching and learning methods. Namely, with the shift from the traditional to a functional approach to teaching in many disciplines, teaching expands beyond the classical lecture-and-note approach and is becoming increasingly centred on interaction in the classroom and on enhancing cooperation among students. The English language classroom is often filled with heterogeneous groups of students who have quite different levels of language proficiency, especially in terms of grammar knowledge, and as a result students have different interests and needs in terms of teaching and learning methods that actually help students improve their knowledge of English as a foreign language (EFL).

The purpose of this paper is to systematically reflect on the teaching methods applied in the English grammar classroom at the authors' institution as well as to track student progress in learning grammar over a period of two semesters. Based on the research results after teaching those courses for two semesters, the authors suggest an adequate teaching approach for the EFL classroom, with special focus on grammar. Namely, this paper aims to answer two questions:

(1) Do grammar teaching methods affect student achievements? If the answer to this question is positive, it is important to analyse which are the most effective teaching methods in the grammar classroom; and

(2) Is it necessary to track progress achieved by students in the EFL classroom throughout their undergraduate studies (in addition to taking exams)? If the answer to this question is also positive, it is important to discuss introducing progress tracking on a national level.

\section{Towards a Functional Teaching Approach in the English Language Classroom}

Traditional teaching of foreign languages in many South-eastern European countries was focused on teachers rather than on students who were passive observers of teachers' explanations and learned the material presented by the teacher by memorizing (Bérešová 2017: 959). This is especially true for grammar; however, English language teaching in recent years has shifted the focus from the traditional approach towards a more innovative functional approach to teaching. Students often criticize the classical lecture-and-note approach because it usually results in unproductive learning, passive students, lack of classroom interaction, lack of research inside and outside of the classroom, disregarding of student opinion on course content and significant teacher-reliance (Sazdovska-Pigulovska 2017: 84).

Grammatical competence is defined as "knowledge of, and ability to use, the grammatical resources of a language" (CEFR: 112). It implies "the ability to understand and express meaning by producing and recognising well-formed phrases and sentences in accordance with these principles (as opposed to memorising and reproducing them as fixed formulae)" (ibid., 113). Grammar is often considered 
by students the most difficult part of foreign language acquisition, and mastering grammar theory and practice is often a daunting and unexciting experience for many students, who often end up as passive observers of the teacher's theoretical explanations in grammar class. Therefore, this paper analyses the effects on student achievements when integrating an action-oriented approach in grammar teaching and learning and abandoning the traditional methods under the classical teacher-centred approach.

Previous research on cooperative learning for grammar classes at undergraduate studies by Ghorbani and Nezamoshari (2012), who tested several hypotheses with first-year EFL students, showed that cooperative learning clearly improves EFL students' grammar achievements in such a way that both lower and higher achieving students improve knowledge when they are responsible for their own learning and when they support each other in groups (2012: 1468). Furthermore, Kezoui (2014) conducted a study among second-year EFL students and concluded that cooperative learning significantly boosted EFL learners' grammar competence because when students joined efforts and learned grammar in groups it raised their motivation to learn and supported personal, academic and social growth as well (2014: 84-85). All of these authors find a strong correlation between motivation and academic achievements as cooperative learning methods facilitate the learning process.

By applying a functional approach in the English grammar classroom, the focus is shifted from predominantly theoretically-based lectures in grammar to hands-on experience through communicative activities and cooperative methods with high student involvement and cooperation in the learning process. Namely, the cooperative learning approach is an instructional technique where learning occurs while students work together in small groups to achieve a common goal (Slavin 1991). In this way the teacher puts a focus on the needs of the students and systematically analyses how their teaching is affecting learners rather than making assumptions on its effects on students. In order to determine whether this teaching approach is applicable for the grammar classroom, the authors of this paper conducted an authentic survey, whose details are presented in the next section.

\section{Methodology}

For the purposes of this paper, the authors conducted a survey in the 2017/2018 academic year among 50 first-year students at the Department of Translation and Interpreting, within the "Blaze Koneski" Faculty of Philology in Skopje, who study EFL in the first four semesters of their undergraduate studies. This paper aims to suggest improved teaching methods in the English language classroom with special focus on grammar, and to highlight a need for improved curricula for all EFL courses at the Faculty of Philology. Furthermore, the final goal of this paper is to open a discussion on the need to systematically track the level of language progress achieved by students throughout their studies, as well as to discuss the need for introducing progress tracking across philological faculties in the Republic of North Macedonia.

The authors used the following instruments for collecting data: 
- English grammar placement test: a first test available online was taken by surveyed students at the beginning of the first semester, which determined the students' entry level of grammatical competence in accordance with the Common European Framework of Reference for Languages (CEFR), which allows skills to be tested separately; ${ }^{1}$

- a paper-based questionnaire: tailored by the authors specifically for the needs of the research presented in this paper and completed by students after finishing the first semester of the English grammar courses, which provided insight into students' personal opinions on the effectiveness of applied teaching methods in the English grammar classroom and their preferred learning methods; and

- a follow-up English grammar placement test: a control test available online was taken by surveyed students after completing the second semester of the English grammar course, which determined their new level of grammatical competence in accordance with the CEFR and showed whether the students achieved progress in terms of grammar knowledge in a period of one academic year by comparing the results of both tests.

The students anonymously filled out a semi-structured questionnaire with 10 questions, which were either pre-determined questions (dichotomous questions with a "yes" or "no" response or multiple-choice questions) or open-ended questions requiring respondents' explanations. All results and statistical data are presented in 12 figures in this paper and present authentic authors' data. The purpose of the combined survey research is to reveal students' personal opinions on key aspects related to classroom activities and to help track students' grammar progress in a period of one academic year. The authors have already made extensive use of the survey results to properly develop the teaching curriculum for the grammar course and in integrating efficient grammar teaching methods and activities that contribute to higher academic achievements.

\section{Results of the Research}

The motivation for conducting this research comes from the fact that the English language classroom at the authors' department was often composed of heterogeneous groups of students with quite different levels of English language proficiency, especially in terms of grammatical competence. This usually results in students having different strengths and weaknesses as well as different interests and needs, whereas conventional methods under the teacher-centred approach mainly proved ineffective for weaker students or too mundane for advanced students. As a first step, an English grammar placement test was taken by 50-first year students at the beginning of the first semester, which provided the authors with insight into the students' entry level of grammar competence in accordance with the CEFR, as presented in Figure 1.

\footnotetext{
${ }^{1}$ At some European universities, students pay a small fee when enrolling undergraduate studies in order to take an Oxford placement test which determines their entry level of language competence in accordance with the CEFR.
} 


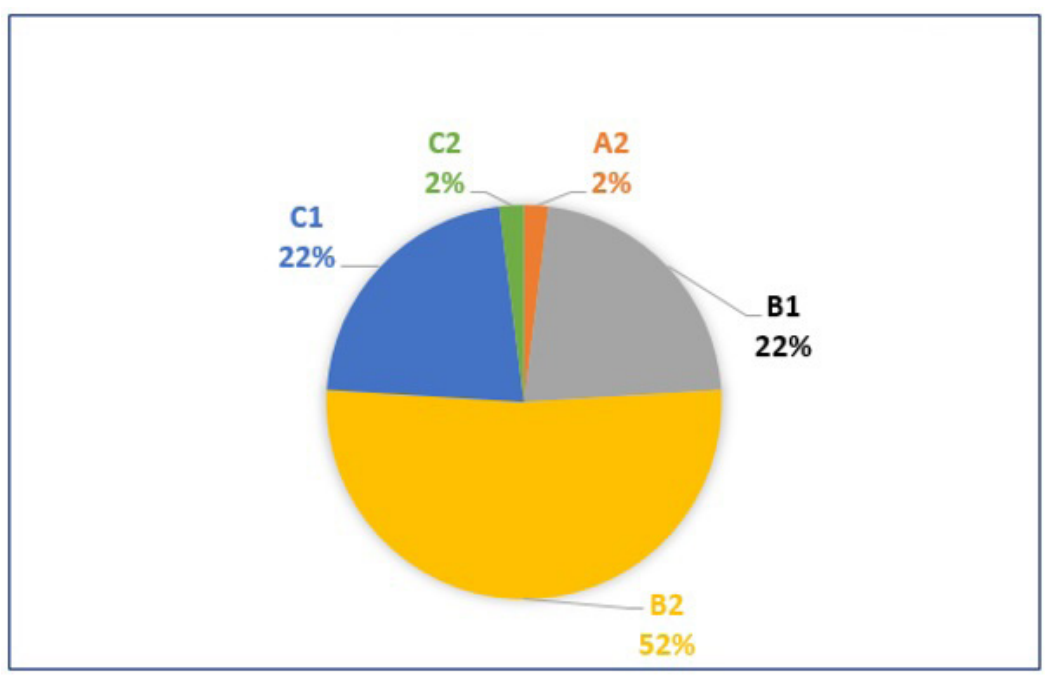

Figure 1. Grammar Entry Level of Enrolled Students

The results presented in Figure 1 showed a heterogeneous group composed of students with different levels of grammatical competence determined with the placement test. In particular, one student was placed at the basic A2 level $(2 \%$ of surveyed students), 11 students were placed at intermediate B1 level (22\%), a majority of 26 students were at advanced B2 level (52\%), 11 students were placed at proficient $\mathrm{C} 1$ level $(22 \%)$ and one student at the highest $\mathrm{C} 2$ level (2\%). This diversity has always been considered a tremendous challenge, which resulted in reintroducing an entry exam as a criterion for enrolment at the Department for Translation and Interpreting. However, this only partially fixed the problem. Namely, since traditional methods of teaching applied in the past did not produce any visible improvement in grammatical competence, the authors saw a need to introduce an action-based approach to teaching based on cooperative learning and to track student progress in terms of grammatical competence over a period of two semesters. Cooperative learning and task-based learning are extensively used approaches and are considered "a potentially productive approach for a number of ESL/EFL teachers" because they provide learners "with the context and conditions where language acquisition can take place" (Hismanoglu and Hismanoglu 2011: 50-51).

The goal of the questionnaire was to provide insight into student opinion on the teaching methods implemented in the English grammar classroom during the first semester, and to reflect on their effect on grammar learning. The results were aimed at improving classroom activities in the second semester of the grammar course that could improve student achievements. In particular, the first section of the questionnaire analyses which learning methods and classroom environments are preferred by the surveyed students (questions 1-3). The results of the first question reveal students' personal opinions on whether they improved their knowledge of English grammar after completing the first semester of the grammar course, which are statistically presented in Figure 2. 


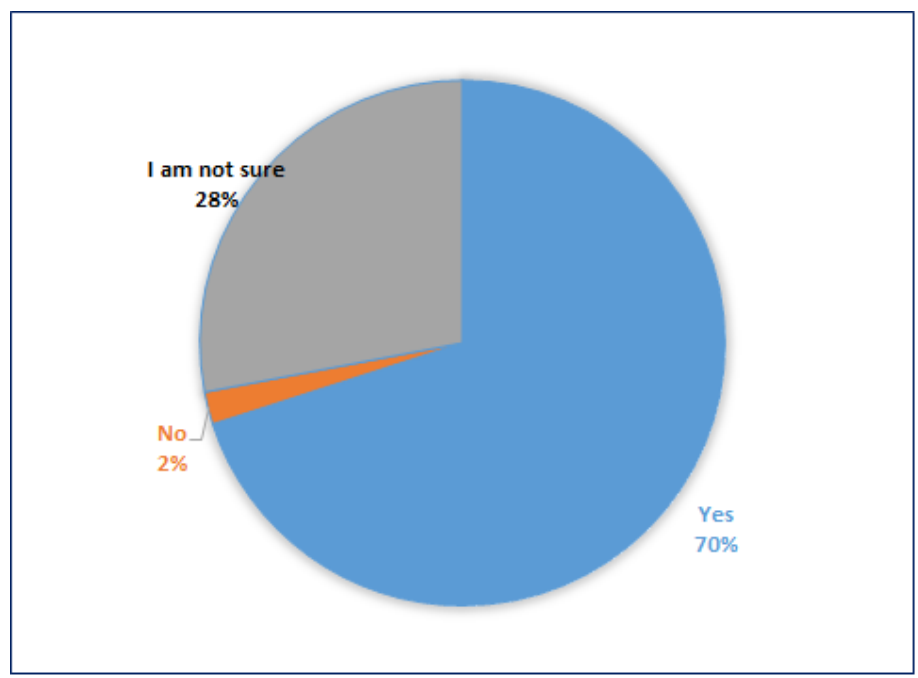

Figure 2. Student Opinion on Improving Their Grammatical Competence

Figure 2 shows that as high as $70 \%$ of those surveyed (35 students) responded that they had improved their grammatical competence after completing the first semester of the grammar course, $28 \%$ (14 students) were not certain whether they had improved their grammatical proficiency, and $2 \%$ believed that they had no improvement (one student). These are only impressionist responses given by students on the basis of their personal opinions, which reveal that many students are not always certain as to whether they achieve actual progress in grammar learning (or how much progress they achieve) and many students solely focus on passing the exam. The next question analyses students' opinions on their preferred learning environment that they believe contributes to efficient grammar learning, as presented in Figure 3.

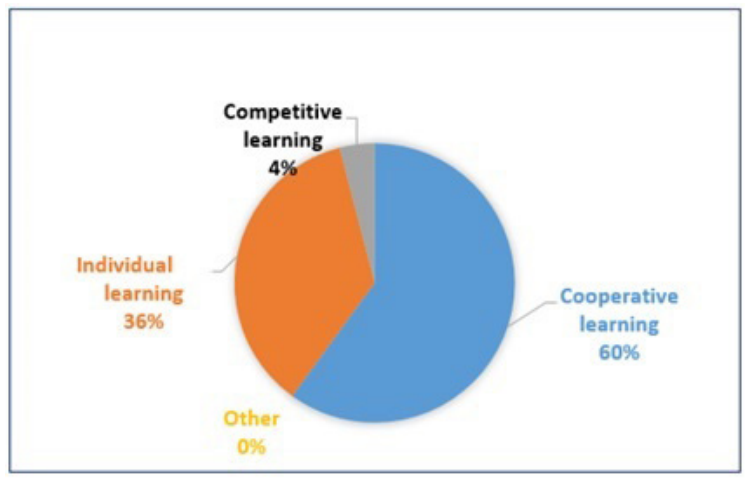

Figure 3. Preferred Learning Environment by Students

Figure 3 shows that the results of the second question reveal that $60 \%$ of those surveyed (30 students) mainly benefited from cooperative learning. The cooperative learning approach is an instructional technique where learning occurs while 
students work together in small groups to achieve a common goal (Slavin 1991). A collaborative classroom implies learning in a cooperative environment with active student involvement and high interaction during grammar lectures and practical exercises, where groups of students set common objectives and jointly work on achieving them. Cooperative learning has 5 basic elements in order for cooperation among learners to take place: positive interdependence, face-to-face promotive interaction, individual accountability, social skills and group processing (Alsanie and Sabir 2019: 110-111). On the other hand, 36\% (18 students) replied that they preferred individual learning, which implies that a student sets his/her own learning goals and works independently on achieving them, with very limited cooperation with other learners. If the classroom integrates an individual style of learning, students are less cooperative and rather self-dependant because they complete assignments individually and sometimes even turn into passive observers of teacher's lectures (Kezoui 2014: 9). Finally, only 4\% (two students) said that they preferred learning in a competitive environment. According to Kezoui (2014), in a competitive classroom, classmates compete with each other and compare achievements, which can be stimulating as the success of their peers motivates other students to study harder and to catch up with well performing peers. Although this is stimulating for some students, it could result in disregarding cooperation with peers and focusing on grades and credits. The high response in favour of cooperative learning is the first indicator that highlights a need for integrating an action-based approach to teaching grammar. Hence, during both semesters of the grammar course, a cooperative classroom was organised in such a way that surveyed students learned by cooperating and interacting with peers. Namely, they worked together in small groups and jointly completed research and assignments (instructed by the teacher) inside or even outside of the classroom in order to master a grammar topic covered in class. According to Johnson, Johnson and Holubec (2008: 24), face-to-face promotive interaction includes: group work, exchange of materials, students assessing each other's performance, students challenging each other for higher quality outcomes, trust between students and group members contributing to achieving a mutual goal.

The cooperative instructional technique is the opposite of a conventional teacher-centred approach. Namely, the authors did not enforce a work method or schedule on students, but only observed how the learning groups worked on a specific grammar topic and instructed them if necessary. According to Johnson (1991), the teacher's role in planning formal cooperative learning groups includes: providing instructions to students, organising students into groups, explaining the assigned task, controlling the functioning of each group, teaching social skills, providing feedback on students and groups and evaluation of student progress using a criterion referenced test (Johnson et al. as cited in Kezoui 2014: 20-21).

To conclude, in reality the least utilized learning method in the English language classroom is usually the cooperative method. However, when cooperative learning is the preferred learning environment by students (as in this specific case), the teacher must choose cooperative learning strategies that will benefit all students. In order to make a wise selection of classroom activities, students' opinion was taken 
into consideration on the most efficient grammar learning method after completing the first semester of the grammar course.

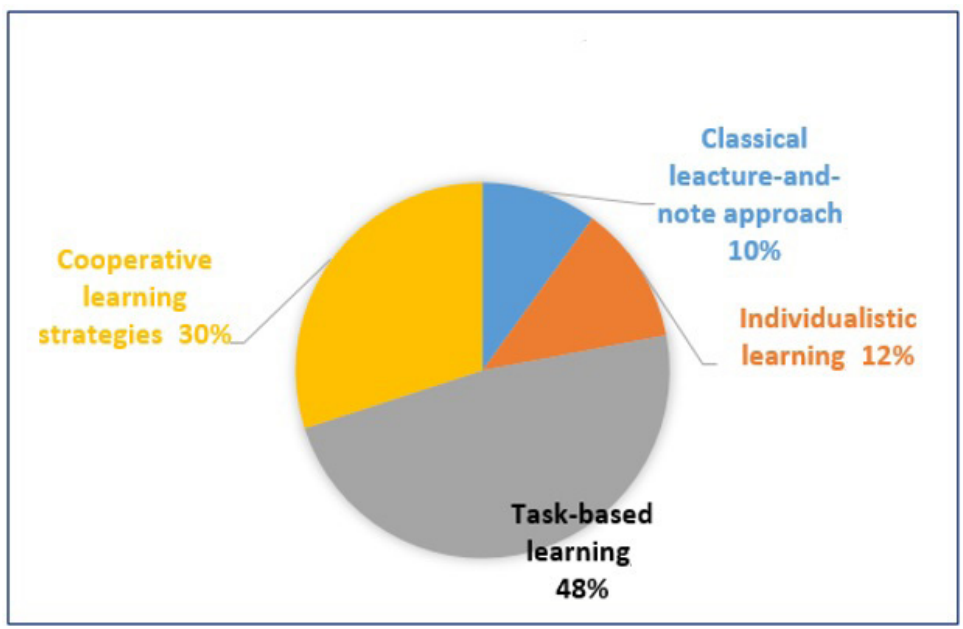

Figure 4. Student Opinion on the Most Efficient Grammar Learning Method

Figure 4 presents the students' responses on what they believed contributed to grammar mastery. Forty eight percent of those surveyed (24 students) indicated task-based learning as the most efficient method for mastering grammar. Taskbased language teaching (TBLT) promotes language learning by performing tasks, whereas the tasks must be adapted to students' linguistic proficiency levels (Hismanoglu and Hismanoglu 2011: 51). The surveyed students explained that learning grammar by performing specific tasks in pairs or in small groups proved to be very productive because it stimulated them to rely on themselves for answers on a grammatical topic. An additional benefit is that by performing communicative tasks or assignments, students interact with peers by presenting ideas to their group, comparing results and consulting peers for explanations rather than the teacher.

The second most useful method indicated by $30 \%$ (15 students) are the so-called cooperative learning strategies, which helped the students learn how to cooperate with others in the learning process and to rely on other group members for feedback. The least useful method indicated by surveyed students was individual learning ( $12 \%$ or 6 students), which involves independent learning usually at home and with low student interaction (often even without regularly attending the grammar course), followed by the classical lecture-and-note approach $(10 \%$ or 5 students), which involves the teacher providing explanations during class and students passively taking notes and completing whole-class activities with low interaction. These results demonstrate that some students are mainly accustomed to individual work and need more time to adapt to a communicative classroom involving group work in the process of learning as well as need guidance on developing communicative skills.

The combined $78 \%$ response rate in favour of task-based and cooperative learning implies an opportunity for integrating communicative exercises and for explor- 
ing the opportunities of collaborative learning in the grammar classroom. These two effective approaches affect students' perception of learning as students gradually start to see the learning process as a two-way process and become increasingly aware that knowledge does not only come from the teacher, but that learning also happens in cooperation with peers. Richards and Rodgers (2001) explore approaches and methods in language teaching and conclude that tasks are an effective tool for facilitating the learning process as well as classroom activities that enable students to make conclusions by observing how language is used in communication and to consult with peers for explanations.

The above questionnaire results demonstrate that grammar learning is facilitated when students learn cooperatively and when they communicate effectively among each other. In fact, productivity significantly increases when learning grammar is not experienced as passive formal instructions isolated from communicative work and tasks. Therefore, the second part of the questionnaire analyses which grammar teaching methods were implemented by the authors at the English grammar course (questions 4-9). Figure 5 shows how students described the grammar course after completing the first semester.

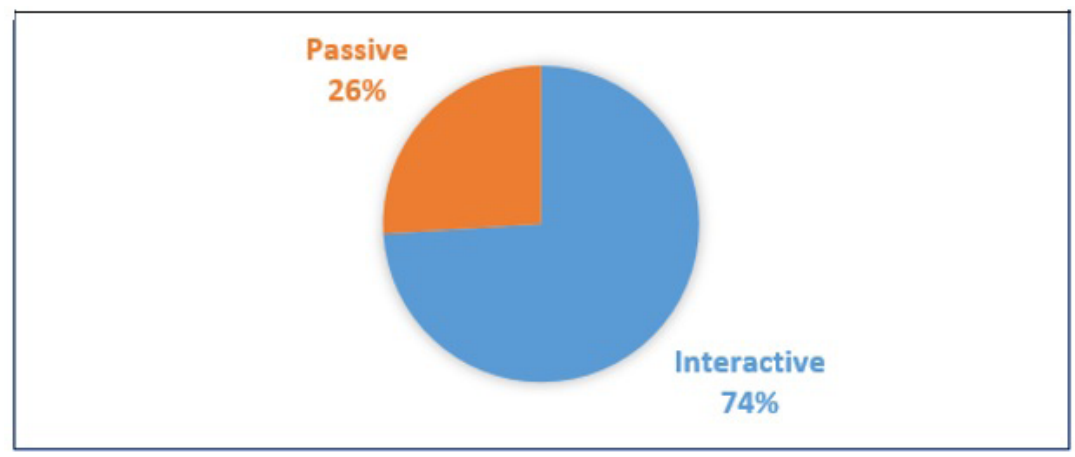

Figure 5. Student Opinion on the Grammar Course

The results presented in Figure 5 show that as high as $74 \%$ (37 students) described the grammar course as interactive, whereas $26 \%$ (13 students) described it as passive. These results are an important indicator, because if learners believe that they are part of a passive classroom it will decrease their motivation to become actively involved in communicative classroom activities. A passive classroom is unproductive because it does not improve student achievements and competences. An active or communicative learning environment is therefore much more suitable for grammar learning because it increases student motivation to become active learners, and motivation directly affects student achievements. Even though the grammar course was mainly described as interactive, the next question shows whether students believed that they were personally interactive during grammar class. Students' responses are summarized in Figure 6. 


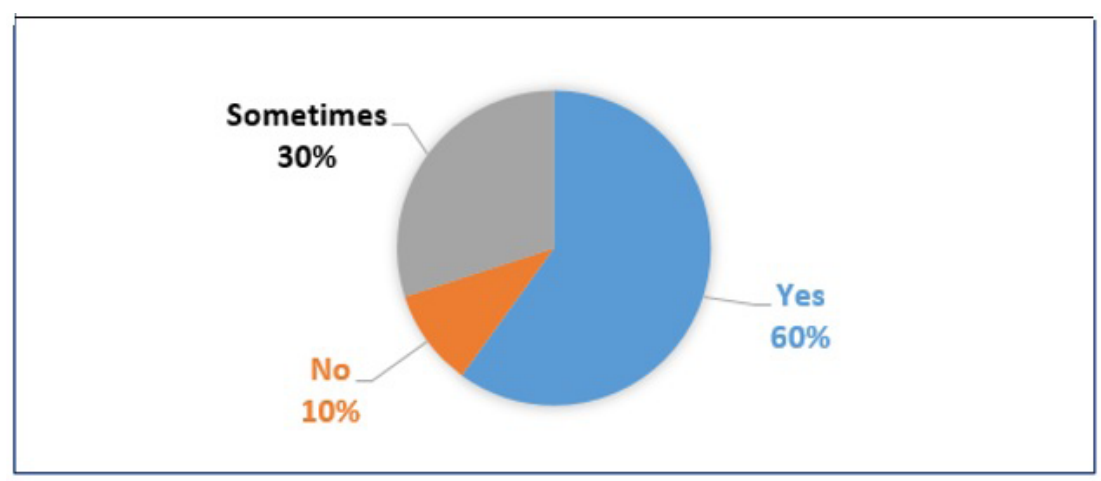

Figure 6. Personal Interactive Involvement During Grammar Classes

Figure 6 shows that $60 \%$ (30 students) responded that they were personally interactive during the grammar course, whereas 30\% (15 students) admitted that they did not always take on an active role in the grammar classroom during the first semester, and $10 \%$ (five students) were fully aware that they were not interactive during grammar classes. These results show that grammar teaching must be reinforced with cooperative learning methods that imply active student involvement in the learning process and contribute to higher achievements. The combined $40 \%$ response rate was an indicator that changes were necessary in terms of improved classroom activities to be included in the second semester of the grammar course. Therefore, students were asked how they would personally change or improve classroom activities for grammar in the second semester by drawing on their personal experience. Student responses are summarized on the next figure.

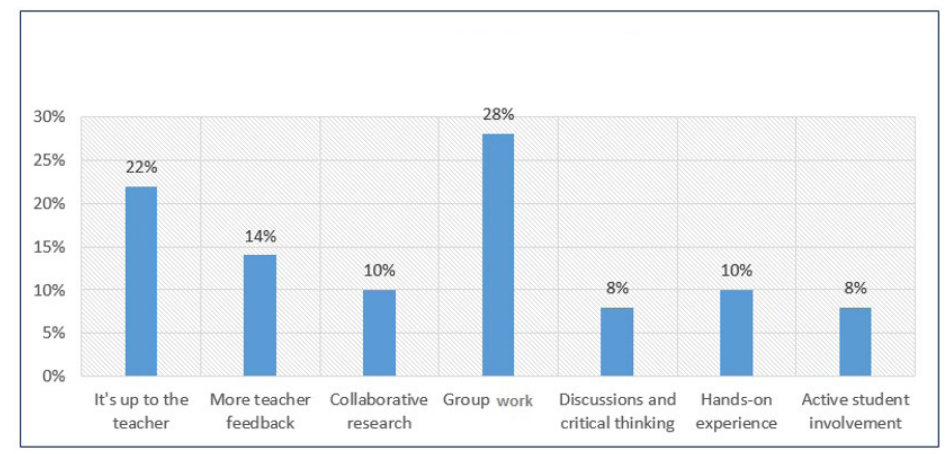

Figure 7. Student Suggestions for Improving the Grammar Course

The above suggestions given by surveyed students demonstrate that $28 \%$ (14 students) proposed including more group work in the second semester of the grammar course. According to Johnson, Johnson and Holubec (2008), under the cooperative learning approach, three types of groups can be organised: formal, informal and base cooperative learning groups. This reply was followed by $10 \%$ (five students) who explained that they would prefer to engage in more collaborative research with peers in the second semester and thus avoid the classical and perhaps monot- 
onous lecture-and-note approach and excessive teacher-reliance that is still applied in grammar teaching at certain faculties. Some suggested having more discussions among students and assignments that stimulate critical thinking ( $8 \%$ or 4 students), for example in relation to use of passive or differentiating between the different types of conditional sentences. Others suggested mastering grammar through more hands-on experience in the second semester instead of excessive teacher-reliance for answers (10\% or 5 students) and active student involvement in the learning process ( $8 \%$ or 4 student), for example corpus-based research of conditional sentences. All suggestions favour an active role by students, compared to a smaller group who believed that grammar teaching methods for the next semester should be selected by the teacher ( $22 \%$ or 11 students), which implies a rather passive role of these students together with the those who indicated that they would prefer to get more detailed grammar explanations from the teacher during grammar classes $(16 \%$ or 8 students).

Based on the above student suggestions, the second semester of the grammar course was reinforced with cooperative learning methods. In particular, the following techniques were introduced in the grammar classroom: ${ }^{2}$

- Learning together (LT) is a cooperative learning method that involves creating learning groups of 4-5 students who work together on the same assignment. A typical activity implemented by the authors is when surveyed students were asked to discuss together the use of relative clauses, so they performed joint research on this topic, shared ideas within their group and sought proper strategies to complete the assignment without teacher reliance. This assignment prompted everyone to become involved in research. According to Johnson, Johnson and Holubec (2008), learning groups are distinguished from traditional groups by five elements: positive interdependence among group members, face-to-face interaction, individual accountability of all members, social skills for effective communication and group processing through leadership, decision-making, conflict-management and feedback. This type of learning showed that students learned much more when they were expected to teach the material to the rest of the group;

- Group investigations (GI) is a cooperative learning method where usually four students are involved in group projects. For example, the surveyed students planned their work, divided work among each other, did individual research on a different topic, for example exploring academic use of passive voice, examined results together, and then jointly presented the project to the whole class with each group member presenting a specific aspect of the project. Through this strategy, students exercised critical thinking, team work and social skills, which enabled them to learn more effectively during the second semester;

- Student teams-achievement divisions (STAD) is introduced by Slavin (1994) and it is a commonly applied cooperative learning method in teaching grammar, especially when students with different language competences work together.

\footnotetext{
${ }^{2}$ Kezoui (2014) describes five cooperative learning methods: Jigsaw, Student teams-achievement divisions, Learning together, Guided reciprocal peer questioning, and Reciprocal teaching.
} 
By forming such divisions, students had to master the same grammar topic as a group, but were then individually tested on that topic by the teacher, and received scores and credits both on quiz performance and on cooperation; and

- Task-based learning (TBL) is cooperative learning method which enables students to share ideas, to compare results, to learn from observing how language is used and it is similar to problem-based learning. A typical activity implemented by the authors is when students read lyrics of popular songs or watched a part of a popular movie in order to explore the use of conditional sentences. Such tasks involve learning from communicative tasks and situations that students can relate to, thereby exercising social skills and problem-solving skills, rather than learning from generalised textbooks or from teacher's notes.

To sum up, the results presented in Figure 7 show that although students preferred group work and student autonomy by engaging in cooperative learning activities and interactive work (64\%), some students still favoured teacher-reliance $(36 \%)$. On the other hand, these results reveal the preferred role of students in the classroom. which is nresented in Figure 8.

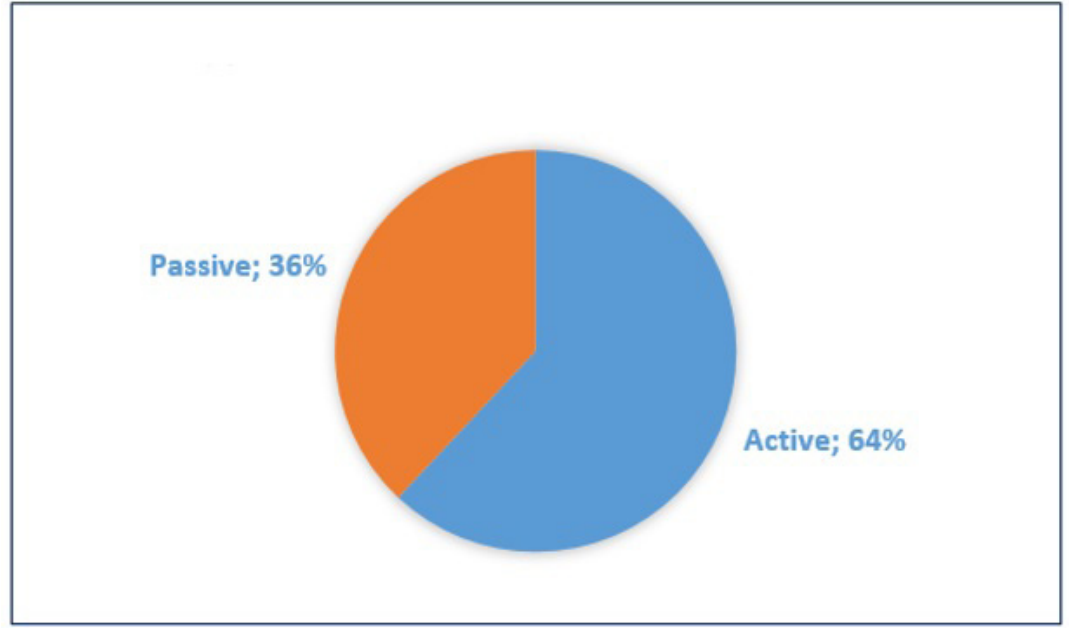

Figure 8. Student Role in the Classroom

As shown in Figure 8, the previously suggested activities by surveyed students show that as high as $64 \%$ of them (32 students) prefer to have an active role in the learning process, whereas $36 \%$ (18 students) prefer to remain in their comfort zone and to have a passive role in the grammar classroom. An active role means that students have a say in choosing methods for acquiring knowledge and that they actively take up collaborative research and group work. This result is a clear indicator that an action-oriented approach needs to be integrated in the English grammar classroom with high level cooperative learning methods. However, it is difficult to implement cooperative learning methods and communicative tasks during online education (following the global Covid-19 pandemic). Currently this remains a challenge for all EFL teachers who must invest additional efforts to find adequate alternatives. 
Moreover, students need to take on an active role in language learning whether it is for acquiring knowledge of something practical like vocabulary or of something a theoretical like grammar. After the surveyed students were more involved in active learning in the second semester, their motivation to become actively involved in the learning process visibly increased. Once motivated, students interacted with each other more in the second semester (which was not the case over the past years when the students were usually passive listeners of the teacher's explanations when the traditional teacher-centred approach was implemented in the grammar classroom). Higher motivation was achieved when the surveyed students were involved in the above-mentioned cooperative learning methods, whereas the results of this research also show that motivation directly affects learning achievements.

After introducing the suggested changes and cooperative learning methods during the second semester, the students took a control grammar placement test after completing the second semester of the grammar course, which determined their level of English grammar knowledge and possible improvements. The results of the control grammar placement test are presented in Figure 9.

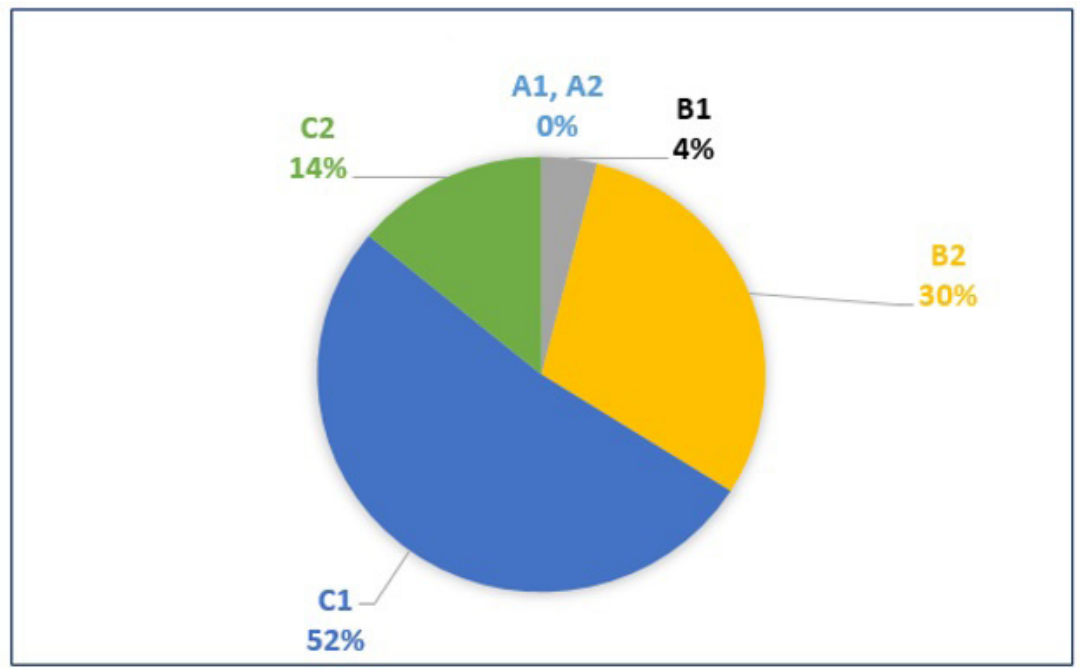

Figure 9. Ex-post Grammar Level

As shown in Figure 9, the results of the control grammar placement test showed a much more homogeneous group composed of students with improved level of grammatical competence, as the majority of students were placed on advanced levels after completing the second semester of the grammar course. In particular: no students were placed at the basic A2 level $(0 \%)$, with only 2 students placed at intermediate B1 level (4\%) and 15 students at B2 level (30\%), and this time there were much more advanced students placed at $\mathrm{C} 1$ level (52\% or 26 students) and even seven students were placed at the highest C2 level (14\%). Furthermore, by comparing the results of the entry test (Figure 1) and the results of the control test (Figure 9), a conclusion can be made that the applied teaching methods in the second semester of the grammar course significantly affected the learning achievements of students and measured actual progress in grammatical proficiency, 
which provides an answer to the first question in this paper. Namely, the extent of students' achievements in a period of two semesters is statistically presented in Figure 10, which shows that 8 students $(16 \%)$ achieved significant improvement in grammar proficiency by moving two levels up the CEFR scale (mainly from B1 to $\mathrm{C} 1$ and from $\mathrm{B} 2$ to $\mathrm{C} 2$ ). This had never happened before with previous students when the teacher-centred approach was mainly applied in the English grammar classroom and students mainly focused on passing the exam rather than on acquiring knowledge.

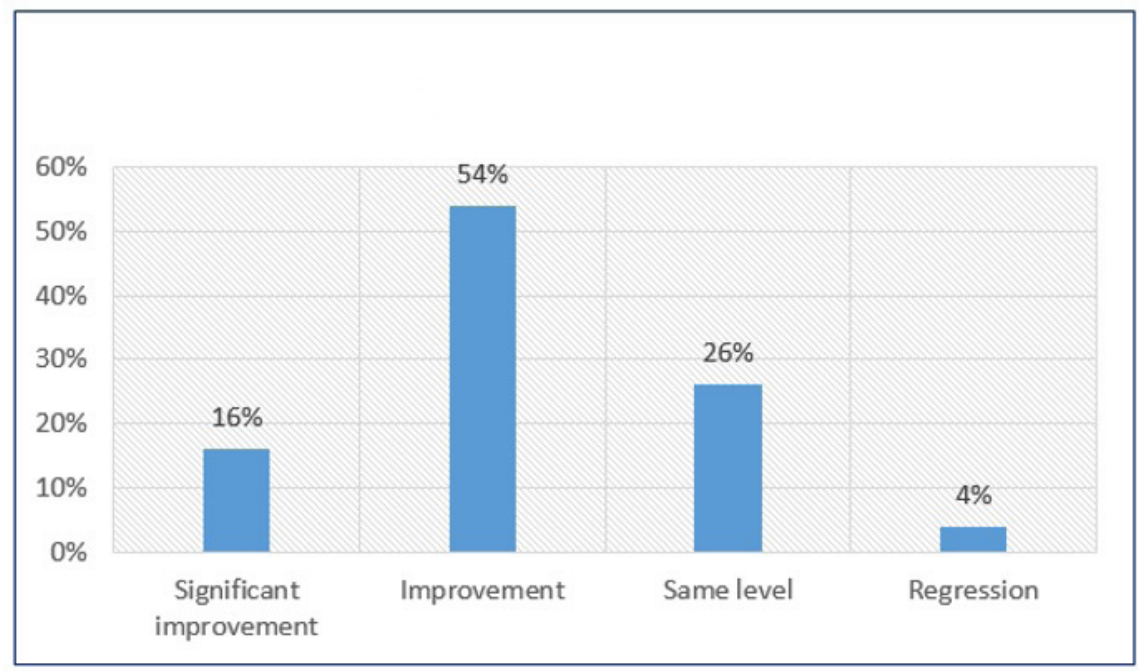

Figure 10. Improvement in Students' Achievements

Furthermore, Figure 10 shows that as high as 27 students (54\%) achieved improvement in grammatical competence by going one level up the CEFR scale (mainly from B2 to C1), whereas 13 students $(26 \%)$ remained at the same level (mainly maintained $\mathrm{B} 2$ or $\mathrm{C} 1$ level). The data also show a negative trend with 2 students (4\%) experiencing regression by going one level down from B2 to B1, who failed to regularly attend the grammar course. This negative trend shows that the cooperative learning approach proves ineffective when students do not attend classes regularly and prefer an individualistic approach in learning that is isolated from the peers and the teacher instructions and lacks peer discussions that promote critical thinking. Hence, it is not an easy task to implement cooperative learning methods during online classes and education (following the global Covid-19 pandemic). To conclude, Figure 10 clearly demonstrates improvement in students' achievement, which is owed to applying cooperative learning methods.

\section{Discussion on Progress Tracking}

Finally, the third part of the questionnaire analyses student opinion on the importance of tracking grammar progress (questions 9-10). Bearing in mind the above results, students were asked whether they believed that it was important to track their progress of overall English language competence throughout their four-year 
undergraduate studies (in addition to taking exams) and the results are presented in Figure 11.

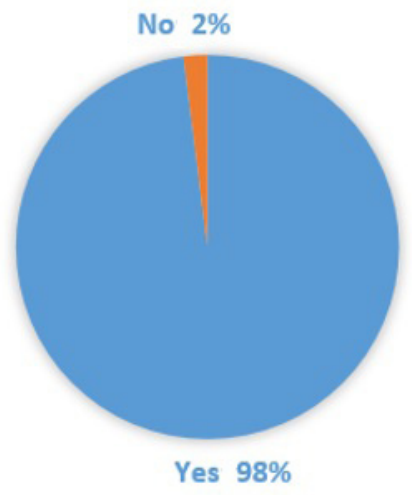

Figure 11. Student Opinion on the Importance of Progress Tracking

Figure 11 demonstrates that as high as $98 \%$ (49 students) believe that it is important to track the overall language progress they achieve, instead of being unaware of actual progress and only focusing on passing the exam, whereas only $2 \%$ (one student) believe that it is not important to track their language knowledge progress throughout their undergraduate studies. The more detailed explanations provided by surveyed students as to why progress tracking would be useful are presented in the next figure.

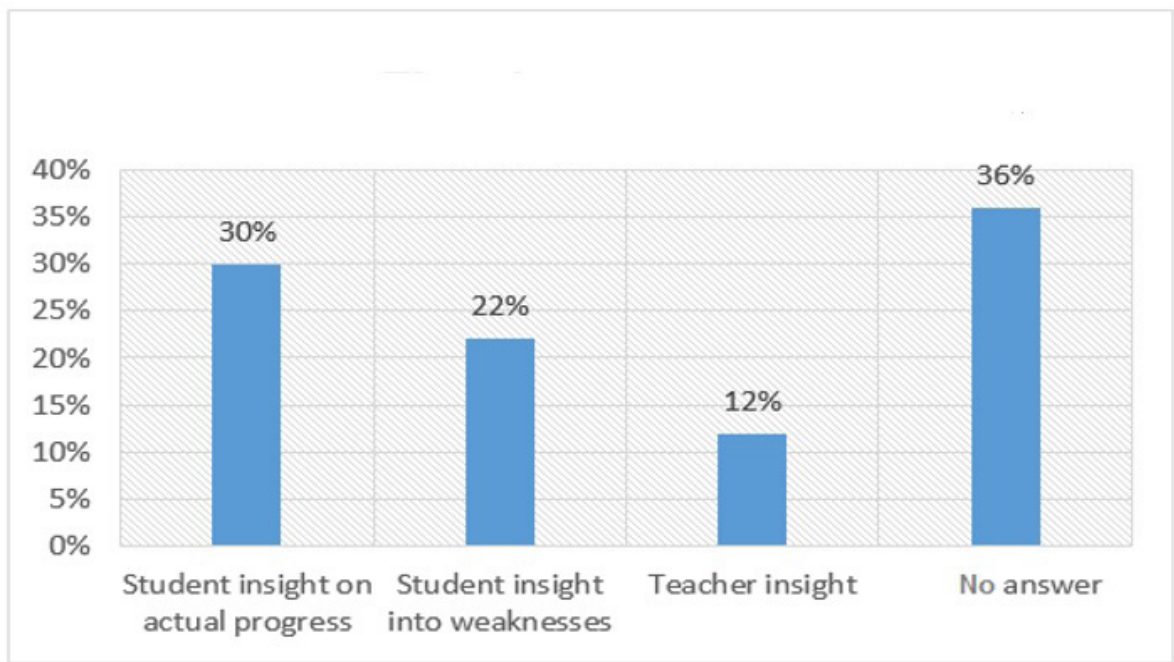

Figure 12. Student Explanations on the Importance of Progress Tracking 
Namely, 30\% (15 students) believe that tracking their overall language progress throughout their undergraduate studies would be useful because they must be aware of whether they achieve actual progress or not, especially considering that the surveyed students had different levels of English language competence (including grammatical competence). Others (22\% or 11 students) support progress tracking because they believe it will enable them to perceive their biggest weaknesses in terms or language competence. $12 \%$ (6 students) believe that progress tracking is important because it will also provide insight for the teacher who could thus adjust the classroom activities to students' realistic needs and expectations. This answers the second question raised in this paper and opens a discussion on whether this should be systematically implemented across Faculties of Philology in the Republic of North Macedonia. Furthermore, the ultimate goal of progress tracking is for students to become aware of whether they are mastering all language areas and to achieve progress by advancing to a higher level on the CEFR scale.

\section{Conclusions}

Over the past years the authors perceived that one of the greatest weaknesses of first-year students was grammatical competence. Traditional methods of grammar teaching applied in the past did not produce any visible improvement and students were not certain how to apply their grammar knowledge in practice, in second and third academic year. On the basis of the results of the conducted research, it is safe to conclude that task-based language teaching and cooperative learning strategies find great application in the English language classroom. Both of these strategies come from the learner-centred educational approach. On the other hand, the results indicate a need for progress tracking of linguistic competence. The majority of the surveyed students achieved progress in terms of grammatical proficiency, which needs to be further improved throughout their fourth-year studies. It is therefore necessary to track overall language learning progress from enrolment to graduation at all faculties with EFL learners. Based on these main conclusions, it is possible to make several recommendations.

Firstly, the authors of this paper recommend introducing a mandatory English placement test at the beginning of the first semester for all EFL learners at the Faculty of Philology in order to determine students' level of language and grammatical competence in accordance with the CEFR scale. In this way the teacher avoids making assumptions on students' competence and learning needs, and can adapt the course program in order to meet the diverse individual learning goals and introduce efficient teaching methods. The goal of the teacher must be to create a stimulating learning environment where students adopt knowledge through simulated or real tasks and problems, whereas the final goal is for students to master all areas of linguistic competence and to advance from one CEFR level to a higher level. In terms of testing at the Faculty of Philology in Skopje, learning outcomes are not centrally measured via placement tests, but only through an exam at the end of every semester; however, these exams are not aligned to the CEFR.

Secondly, traditional teaching methods must be replaced with cooperative learning methods, such as task-based language teaching and cooperative learning groups 
by exploring the opportunities of communicative activities. The results show that grammatical proficiency (and overall language competence) as well as student motivation to become actively involved in learning can be enhanced with cooperative learning methods which stimulate students to explore the opportunities of collaborative research, tasks and learning groups. Furthermore, students enhance their communicative skills and problem solving skills in addition to linguistic and grammatical competence.

The follow-up grammar placement test showed that collaborative grammar teaching methods positively affected student achievements. The data analysis showed that the most effective teaching methods in the grammar classroom are task-based learning (indicated by $48 \%$ of surveyed students) and other cooperative learning strategies, such as learning together, groups investigations, student teams-achievement divisions, which resulted in improved grammatical competence. Higher motivation was achieved when the surveyed students were involved in the above-mentioned cooperative learning methods whereas the results of this research also show that motivation directly affects learning achievements. However, it is very difficult to implement cooperative learning methods and communicative tasks during online education (following the global Covid-19 pandemic). Currently this remains a challenge for all EFL teachers who invest additional efforts to finds adequate alternatives.

Thirdly, the research results indicate a strong need for introducing language progress tracking of EFL learners. Hence, the authors suggest introducing mandatory progress tracking for EFL learners at the Faculty of Philology and at all Faculties of Philology in the Republic of North Macedonia. The ultimate goal of progress tracking is for students to master all language areas and to advance to a higher level on the CEFR scale. Progress tracking will benefit all faculties on a national level because it also encourages teachers to reflect on their current teaching methods, to assess their effectiveness for all students in the classroom and to assess the productivity of the classroom, thus improving language teaching and directly contributing to learning progress and improved achievements. Wider discussions are needed on whether student language proficiency should be included in the university diplomas on a national level.

\section{Bibliography}

Alsanie, R. and Sabir, M. (2011). Integrating Cooperative Learning in Reading Classrooms: An Investigation of Saudi EFL Learners' Perception. International Journal of Linguistics, 11 (3): 107-126.

Bérešová, J. (2017). The Impact of the CEFR on Teaching and Testing English in the Local Context. Theory and Practice in Language Studies, 7 (11): 959-964.

Council of Europe. (2011). Common European Framework of Reference for Languages: Learning, Teaching, Assessment. Language Policy Unit, Strasbourg.

Ghorbani, M. R. and Nezamoshari, M. (2012). Cooperative Learning Boosts EFL Students' Grammar Achievement. Theory and Practice in Language Studies, 2 (7): 1465-1471, Academy Publisher Manufactured in Finland. 
Hismanoglu, M. and Hismanoglu, S. (2011). Task-based language teaching: What every EFL teacher should do. Procedia Social and Behavioural Sciences 15: 46-52.

Johnson, D. W., Johnson, R. T. and Holubec, E. J. (2008). Cooperation in the Classroom. 8 Edina, Minnesota: Interaction Book Company.

Kezoui, N. (2014). Cooperative Learning Groups in an EFL Grammar Classes: A Learners' Boost Outcomes. The Case of Second Year EFL Students at Tlemcen University. [Unpublished PhD Dissertation]. University of Tlemcen.

Reem A. and Mona S. (2019). Integrating Cooperative Learning in Reading Classrooms: An Investigation of Saudi EFL Learners' Perception. International Journal of Linguistics 11 (3):107-126.

Richards, J. C. and Rodgers, T. S. (2001). Approaches and Methods in Language Teaching. Cambridge University Press.

Sazdovska-Pigulovska, M. (2017). Implementing a Learner-Centred Teaching Approach in the Field of Philology. International Journal Knowledge in Practice, 20 (1): 83-86

Slavin, R. E. (1991). Student Team Learning: A Practical Guide to Cooperative Learning. Washington DC: National Education Association.

Slavin, R. E. (1994). Student teams - achievement divisions: STAD. Using Student Team Learning, 2(1): 14-18, 20-21, 23-26, 43-47. 
